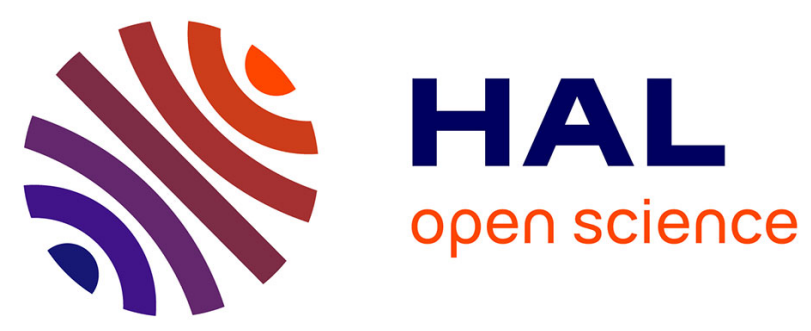

\title{
NMR studies of new arginine vasopressin analogues modified with $\alpha$-2-indanylglycine enantiomers at position 2 bound to sodium dodecyl sulfate micelles
}

Emilia Lubecka, Anna Kwiatkowska, Jerzy Ciarkowski, Emilia Sikorska

\section{- To cite this version:}

Emilia Lubecka, Anna Kwiatkowska, Jerzy Ciarkowski, Emilia Sikorska. NMR studies of new arginine vasopressin analogues modified with $\alpha$-2-indanylglycine enantiomers at position 2 bound to sodium dodecyl sulfate micelles. Biophysical Chemistry, 2010, 151 (3), pp.139. 10.1016/j.bpc.2010.06.002 . hal-00671827

\section{HAL Id: hal-00671827 \\ https://hal.science/hal-00671827}

Submitted on 19 Feb 2012

HAL is a multi-disciplinary open access archive for the deposit and dissemination of scientific research documents, whether they are published or not. The documents may come from teaching and research institutions in France or abroad, or from public or private research centers.
L'archive ouverte pluridisciplinaire HAL, est destinée au dépôt et à la diffusion de documents scientifiques de niveau recherche, publiés ou non, émanant des établissements d'enseignement et de recherche français ou étrangers, des laboratoires publics ou privés. 


\section{Accepted Manuscript}

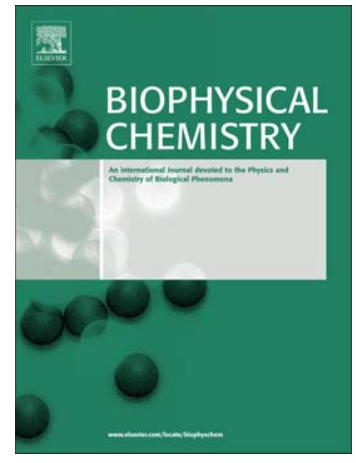

NMR studies of new arginine vasopressin analogues modified with $\alpha-2$ indanylglycine enantiomers at position 2 bound to sodium dodecyl sulfate micelles

Emilia Lubecka, Anna Kwiatkowska, Jerzy Ciarkowski, Emilia Sikorska

S0301-4622(10)00165-1

PII: doi: 10.1016/j.bpc.2010.06.002

DOI: BIOCHE 5404

To appear in:

Biophysical Chemistry

Received date:

28 April 2010

Revised date:

8 June 2010

Accepted date:

8 June 2010

Please cite this article as: Emilia Lubecka, Anna Kwiatkowska, Jerzy Ciarkowski, Emilia Sikorska, NMR studies of new arginine vasopressin analogues modified with $\alpha$ 2-indanylglycine enantiomers at position 2 bound to sodium dodecyl sulfate micelles, Biophysical Chemistry (2010), doi: 10.1016/j.bpc.2010.06.002

This is a PDF file of an unedited manuscript that has been accepted for publication. As a service to our customers we are providing this early version of the manuscript. The manuscript will undergo copyediting, typesetting, and review of the resulting proof before it is published in its final form. Please note that during the production process errors may be discovered which could affect the content, and all legal disclaimers that apply to the journal pertain. 
NMR studies of new arginine vasopressin analogues modified with $\alpha-2$ -

indanylglycine enantiomers at position 2 bound to sodium dodecyl sulfate micelles

Emilia Lubecka, Anna Kwiatkowska, Jerzy Ciarkowski and Emilia Sikorska*

Faculty of Chemistry, University of Gdańsk, Sobieskiego 18, 80-952 Gdańsk, Poland

*Correspondence to: Emilia Sikorska, Faculty of Chemistry, University of Gdańsk, Sobieskiego 18, 80-952 Gdańsk, Poland; e-mail: milka@chem.univ.gda.pl 


\section{ABSTRACT}

In this paper, we use NMR spectroscopy and molecular modeling to examine four new vasopressin analogues modified with $\alpha$-2-indanylglycine (Igl) at position 2, [L-Igl $\left.{ }^{2}\right]$ AVP (I), [D$\left.\operatorname{Igl}^{2}\right] \mathrm{AVP}$ (II), $\left[\mathrm{Mpa}^{1}, \mathrm{~L}-\operatorname{Igl}^{2}\right] \mathrm{AVP}$ (III) and $\left[\mathrm{Mpa}^{1}, \mathrm{D}-\operatorname{Igl}^{2}\right] \mathrm{AVP}$ (IV), embedded in a sodium dodecylsulfate (SDS) micelle. All the analogues display antiuterotonic activity. In addition, the analogues with D-Igl reveal antipressor properties.

Each analogue exhibits the tendency to adopt $\beta$-turns at positions 2,3 and/or 3,4, which is characteristic of oxytocin-like peptides. Mutual arrangement of aromatic residues at positions 2 and 3 has been found to be crucial for binding antagonists with the OT and $\mathrm{V}_{\text {la }}$ receptors. The orientation of the $\mathrm{Gln}^{4}$ side chain seems to be important for the $\mathrm{V}_{\text {la }}$ receptor affinity. In each of the peptides studied, the $\mathrm{Gln}^{4}$ side chain is folded back over the ring moiety. However, it lies on the opposite face of the tocin moiety in analogues with L and D enantiomers of Igl.

Keywords: $\alpha$-2-Indanylglycine; vasopressin; SDS micelle; NMR spectroscopy; molecular modeling.

Abbreviations: AVP, arginine vasopressin; GPCR, G-protein coupled receptor; Igl, $\alpha-2$ indanylglycine; Mpa, 3-mercaptopropionic acid; OT, oxytocin; SDS, sodium dodecyl sulfate. 


\section{INTRODUCTION}

Arginine vasopressin (AVP), a neurohypophyseal hormone and a neuromodulator, is a nonapeptide with a disulfide bridge between Cys residues at positions 1 and 6. It plays a very important role in controlling resorption of water by the distal tubules of the kidney and regulating the osmotic pressure of blood [1,2]. Besides, AVP is responsible for stimulation of the adrenocorticotropine secretion [3] and stability of the body temperature [4]. It exhibits also oxytocic activity [5]. Moreover, recent studies have shown that vasopressin, together with oxytocin, might also take part in autism and provide an effective treatment of autism's repetitive and affiliative behaviours $[6,7]$.

The biological effects of vasopressin are mediated by four different receptor subtypes: $V_{2}$ (renal), $\mathrm{V}_{1 \mathrm{a}}$ (vasopressor), $\mathrm{V}_{1 \mathrm{~b}}$ (pituitary) and OT (uterine), being typical members of class A GPCR, which are membrane-spanning proteins [8]. The current model for peptide hormone interactions with their receptors suggests that the bioactive conformation of the peptide is induced upon association with the cell membrane followed by a two-dimensional diffusion process, whereby the peptide is recognized and then interacts with the receptor $[9,10]$. Therefore, exploring the conformational and dynamic properties of a ligand in a membrane-mimicking environment can contribute to better understanding of the molecular features involved in their interactions with the target receptor.

It is believed that the tyrosine residue at position 2 of AVP plays a part initiating the pressor response of AVP [11]. The substitution of Tyr with its D enantiomer produces an analogue with only partial agonist activity, whereas the deletion or O-alkylation of $\mathrm{Tyr}^{2}$ hydroxyl group results in antagonistic properties [12]. Similarly, replacement of $\mathrm{Tyr}^{2}$ of AVP with bulky or sterically restricted substituents is generally favorable for generation of effective antagonists $[13,14]$.

In this paper, we use NMR spectroscopy and molecular modeling to examine four new vasopressin analogues modified with $\alpha$-2-indanylglycine (Igl) (Fig. 1) at position 2, [L-Igl $\left.{ }^{2}\right]$ AVP (I), [D-Igl $\left.{ }^{2}\right]$ AVP (II), $\left[\mathrm{Mpa}^{1}, \mathrm{~L}^{\left.-\mathrm{Igl}^{2}\right] \mathrm{AVP}}\right.$ (III) and $\left[\mathrm{Mpa}^{1}, \mathrm{D}-\mathrm{Igl}^{2}\right] \mathrm{AVP}$ (IV) embedded in a sodium 
dodecylsulfate (SDS) micelle. Although, dodecyphosphocholine (DPC) provides a zwitterionic surface on the micelle that better mimics the biological membranes of the vertebrates, we decided to use the SDS micelle with negatively charged head groups, because the AVP analogues modified with Igl are poorly soluble positively charged peptides, which advises towards incorporation of net negative charges on the SDS micelle surface in order to improve peptide/micelle solubility [15].

The $\alpha$-indanylglycine was earlier successfully applied for the synthesis of potent and totally enzyme-resistant bradykinin antagonists [16]. In turn, the deamination of cysteine at position 1, usually enhances antidiuretic activity and $V_{2} / V_{1 a}$ selectivity [17]. However, most of oxytocin antagonists describe to date contain Mpa (Fig. 1) instead of Cys $^{1}$ [18].

All the studied analogues exhibit only negligible antidiuretic activity. The [L-Igl $\left.{ }^{2}\right]$ AVP (I) and $\left[\mathrm{Mpa}^{1}, \mathrm{~L}-\mathrm{Igl}^{2}\right] \mathrm{AVP}(\mathrm{III})$ analogues are moderately potent but selective OTR antagonists. In turn, those modified with enantiomer D of Igl have dual activity - they show high antioxytocic potency at low and full oxytocic agonism at high concentrations [19]. This phenomenon is difficult to explain. However, similar effect has been reported for naloxone, an opioid antagonist at low concentration and partial agonist at a high one. The changeover of the activity of naloxone from antagonistic to agonistic is probably the result of a slight desensitization and down regulation of the opioid receptors [20].

\section{MATERIALS AND METHODS}

Peptide synthesis and purification. The peptides were synthesized using the standard 9fluorenylmetoxycarbonyl (Fmoc) methodology (full details including protecting groups, deprotection and cyclication have been reported recently [19]). After HPLC purification, their purity was higher than $98 \%$ as determined by analytical HPLC. The MALDI TOF mass spectrometry confirmed that the purified peptides were the desired products.

Sample preparation. The SDS- $\mathrm{d}_{25}$ was purchased from Sigma Aldrich. The samples in the SDS 
micelle were prepared at a concentration of about $4 \mathrm{mM}$ of a peptide in $0.7 \mathrm{ml}$ of a partially deuterated phosphate buffer $\left(90 \% \mathrm{H}_{2} \mathrm{O}\right.$ and $\left.10 \% \mathrm{D}_{2} \mathrm{O}\right)$ of $\mathrm{pH}=7.4$ containing about $35 \mathrm{mg}$ of SDS$\mathrm{d}_{25}$. The SDS- $\mathrm{d}_{25}$ :peptide ratio was adjusted to approximately 1:40. The SDS- $\mathrm{d}_{25}$ concentration exceeded considerably the critical micelle concentration of SDS $(8.3 \mathrm{mM})$, to be sure that the peptides were indeed micelle-bound.

NMR measurements. All the NMR experiments were recorded on a $500 \mathrm{MHz}$ Varian spectrometer equipped with a Performa II gradient generator unit, WFG, Ultrashims, a high stability temperature unit and a $5 \mathrm{~mm}{ }^{1} \mathrm{H}\left\{{ }^{13} \mathrm{C} /{ }^{15} \mathrm{~N}\right\}$ PFG triple resonance inverse probe head (Intercollegiate NMR Laboratory, Faculty of Chemistry, Gdansk University of Technology, Poland).

The $2 \mathrm{D}$ NMR spectra were taken at $30^{\circ} \mathrm{C}$. The temperature coefficients of the amide proton chemical shifts were measured from 1D NMR spectra at 22, 25, 30, 35, 40, 45 and $50^{\circ} \mathrm{C}$. Proton resonance assignments were achieved by use of the proton-proton total chemical shift correlation spectroscopy (TOCSY) [21], double quantum filtered correlation spectroscopy (DQF-COSY) [22], the nuclear Overhauser effect spectroscopy (NOESY) [23], the rotating-frame Overhauser enhancement spectroscopy (ROESY) [24,25], as well as the gradient heteronuclear single quantum coherence $\left({ }^{1} \mathrm{H}^{13} \mathrm{C}\right.$ gHSQC) [26-28]. All the spectra were measured with a water signal presaturation pulse typically of $2 \mathrm{~dB}$ and $1.5 \mathrm{~s}$. In the case of the $1 \mathrm{D}$ NMR spectra, $16 \mathrm{~K}$ data points were collected and a spectral width of $8 \mathrm{kHz}$ was used. The homonuclear TOCSY (80 ms), NOESY (200 ms), ROESY (200 and $300 \mathrm{~ms}$ ) and DQF-COSY were recorded in the range of 0.5-9.5 ppm, with 32-64 scans per $t_{1}$, a spectral width of $4.5 \mathrm{kHz}$ in both dimensions, and $512 \times 2 \mathrm{~K}$ data sets, which were then zero-filled to $1 \mathrm{~K}$ x $2 \mathrm{~K}$ after Fourier transform. Data size for ${ }^{1} \mathrm{H}-{ }^{13} \mathrm{C}$ HSQC spectrum was $256\left(t_{1}\right)-1024\left(t_{2}\right)$ and spectral widths were $18 \mathrm{kHz}$ in the ${ }^{13} \mathrm{C}$ dimension and $4.5 \mathrm{kHz}$ in the ${ }^{1} \mathrm{H}$ dimension. For this experiment, a total number of 128 transients were used.

Vicinal coupling constants, ${ }^{3} \mathrm{~J}_{\mathrm{HNH} \alpha}$, were assigned using DQF-COSY and 1D NMR spectra. The DQF-COSY spectra were processed to enhance the resolution to $1.2 \mathrm{~Hz}$ per point in F2. For 
Gly residues, the two ${ }^{3} \mathrm{~J}_{\mathrm{HNH} \alpha}$ coupling constants are equal within the limits of error.

The proton chemical shifts were referenced to the $\mathrm{H}_{2} \mathrm{O}$ frequency measured with respect to external 2,2-dimethyl-2-silapentanesulfonic acid (DSS). The ${ }^{13} \mathrm{C}$ chemical shifts were referenced to DSS according to the following relationship: ${ }^{13} \mathrm{C} /{ }^{1} \mathrm{H}=0.251449530$ [29]. The data were processed using VNMR 6.1B (Varian Inc., Palo Alto, CA) and the spectra were analyzed using XEASY [30].

Molecular modeling. The calculations consisted of the following three steps: $(i)$ search of the conformational space by employing molecular dynamics simulations, (ii) simulation of the NOE spectrum and vicinal coupling constants for each conformation, and (iii) determination of the statistical weights of the conformations to obtain the best fit of the averaged NOE intensities and coupling constants to the experimental quantities [31].

Molecular dynamics simulations were carried out with the AMBER force field [32]. The valence geometries of the residues not specified in the standard AMBER database, were parameterized as recommended by the AMBER 9.0 manual [32]. Specifically, these residues were modeled using bond lengths, the valence and torsion angles of appropriate residues and compatible molecular segments taken from the CSDS [33] database. The point charges were optimized by fitting them to the $a b$ initio molecular electrostatic potential $\left(6-31 \mathrm{G}^{*}\right.$ basis set, GAMESS'04 [34] ab initio molecular electronic structure program) for two different conformations of every nonstandard residue, followed by consecutive averaging the charges over all conformations, as recommended by the RESP protocol [35].

The preparation of the micelle was initiated by construction of a single molecule of sodium dodecyl sulfate (SDS) based on the literature parameters [36,37]. The entire procedure has been described by us previously [38]. Initial structures of the peptides were generated in random conformation. The peptide groups were kept fixed to trans geometry with force constant $\mathrm{f}=50 \mathrm{kcal} /$ $\left(\mathrm{mol} \mathrm{x} \operatorname{rad}^{2}\right)$ during the entire simulations. The calculations were performed only for major conformations. Each peptide was placed in a simulation box with its centre of mass coinciding with that of the micelle. Owing to the spherical symmetry of the micelle, the orientation of the peptide 
was unimportant. The side chain of $\mathrm{Arg}^{8}$ and the N-terminus were protonated. Thus, the $\left[\left.\operatorname{Igl}\right|^{2}\right] \mathrm{AVP}$ (I) and $\left[\mathrm{D}-\mathrm{Igl}^{2}\right] \mathrm{AVP}$ (II) had a total charge of +2 , whilst the total charge of $\left[\mathrm{Mpa}^{1}, \mathrm{Igl}^{2}\right] \mathrm{AVP}$ (III) and $\left[\mathrm{Mpa}^{1}, \mathrm{D}-\operatorname{Igl}^{2}\right]$ AVP $(\mathbf{I V})$ was equal to +1 . To neutralize the entire system, chloride ions were added.

To eliminate initial bad contacts between a peptide and the micelle core, and to prevent penetration of water during equilibration, the peptide and the bulk water were kept under weak harmonic constraints with force constants of 10 and $5 \mathrm{kcal} / \mathrm{mol} \cdot \AA$, respectively. These constraints were removed in 20,000 steps of minimization (steepest descent method). The entire system was then minimized for 20,000 steps. Thereafter, the system was equilibrated under a constant pressure at $303 \mathrm{~K}$ for $2 \mathrm{~ns}$. Afterwards, the LES (locally enhanced sampling) [39] system was used. This technique allows selective application of additional computational effort to a portion of the system, thus increasing the sampling of the region of interest. The enhanced sampling is achieved by replacing the region of interest with multiple copies. During the simulation, the copies are free to move apart and explore different regions of conformational space, thereby increasing the statistical sampling. A total of three copies of each peptide were generated by ADDLES module of the AMBER 9.0 program. During MD simulation, a $9 \AA$ cutoff radius was chosen. The MD simulations were carried out at $303 \mathrm{~K}$ in a periodic box of constant volume, with the Particle-mesh Ewald (PME) procedure. The time step was 2 fs. The total duration of the LES run was 4 ns. The coordinates were collected every $2000^{\text {th }}$ step. The conformations obtained during the last 800 ps of simulation were considered in further analysis. As a result, the set of 600 conformations for each peptide was obtained.

Next, the theoretical NOE spectrum and ${ }^{3} \mathrm{~J}_{\mathrm{HNH} \alpha}$ vicinal coupling constants were calculated using the MORASS [40] program for each conformation. This program solves the system of Bloch differential equations for the cross-relaxation of a system of interacting proton spins. The vicinal couplings, ${ }^{3} \mathrm{~J}_{\mathrm{HNH} \alpha}$, were calculated from the empirical Bystrov-Karplus relationship [41]. The NOE effects were generated using a correlation time of $0.45 \mathrm{~ns}$ [42], mixing time of $200 \mathrm{~ms}$ and a cut-off 
value of $6 \AA$. The weight of the coupling-constant term was 0.2 . The populations of the conformations, described by statistical weights, were determined by fitting a linear combination of the generated spectra and coupling constants to the experimental data with an entropy factor, $\alpha=0.2$ [31]. To describe the structural preference of each peptide we used the structures constituting about $60 \%$ of the ensemble obtained from calculations. As a result 194, 111, 24 and 42 conformations of analogues I, II, III and IV, respectively, were considered.

The results were analyzed using the Carnal and Ptraj programs from the AMBER 9.0 package [32]. To find the peptide-micelle interactions, the radial distribution functions (RDFs) between the side chains and negatively charged groups of the SDS micelle and also between the side chains and the micelle core atoms were calculated. The data were averaged over the conformations with the sum of their statistical weights amounting to $60 \%$. To estimate the interactions between the peptides and aqueous environment, hydration numbers were also

calculated, as a method of quantifying the interactions between the peptides and water. The hydration number is an integral radial distribution function showing how many water molecules are located near the residue. Two sets of the hydration numbers were calculated for each system, one for the side chains heavy atoms, and the other for the carbonyl oxygen for each residue for a hydration radius of $3.8 \AA$.

The molecular structures were drawn and analyzed with the MOLMOL [43] graphic program.

\section{RESULTS AND DISCUSSION}

Analysis of the NMR spectra. The NMR spectra of analogue II and IV indicate that the $\mathrm{Phe}^{3}, \mathrm{Gln}^{4}$, $\mathrm{Asn}^{5}$, and $\mathrm{Arg}^{8}$ residues are at equilibrium between two conformational states. In analogue IV, two distinct sets of residual proton resonances were also found for Gly ${ }^{9}$. The intensity ratio of both conformers is equal approximately to $5.6: 1$ for each peptide. On the other hand, only one set of the chemical shifts was found for the remaining residues. The appearance of two conformers is likely to 
be due to either the cis/trans isomerization of the $\mathrm{Cys}^{6}-\mathrm{Pro}^{7}$ peptide bond or different interactions of the peptides with the SDS micelle. The former hypothesis could be verified by an exchange trans $\mathrm{H} \alpha(\mathrm{Pro})-\operatorname{cis} \mathrm{H} \alpha(\mathrm{Pro})$ cross peak and/or cisH $\alpha(\mathrm{Cys})$-cisH $\alpha(\mathrm{Pro})$ connectivity. However, they were not found in the ROESY and/or NOESY spectra. In turn, taking into account the latter hypothesis, strong electrostatic interactions between the positively charged $\mathrm{Arg}^{8}$ side chain and the negatively charged sulfate groups at the micelle surface could be expected. Hence, the $\operatorname{Arg}^{8} \operatorname{should}^{\prime}$ be strongly bound to the micelle surface and a smaller conformational space should be accessible than for the remaining residues. Consequently, only one set of proton resonance for Arg is likely to exist. Therefore, we cannot validate the origin of the two conformers unambiguously. The proton chemical shifts of the peptides are summarized in Tables 1S and 2S (Supplementary Materials).

It is known that the sequential $\mathrm{d}_{\mathrm{NN}}(\mathrm{i}, \mathrm{i}+1)$ NOE connectivities are seen only in those regions of peptides which preferentially adopt folded conformations [44]. Therefore, the scrutiny of the NOE patterns (Fig. 2) suggests that all the analogues adopt primarily reverse structures in their cyclic part. In addition, existence of the $\mathrm{d}_{\alpha \mathrm{N}}(2,4)$ connectivities in the NOESY spectra of analogues II and IV implies a $\beta$-turn at position 2,3 . In the case of compound IV, the $\mathrm{d}_{\alpha \mathrm{N}}(1,4)$ NOE cross-peak found may also indicate $\beta$-turn at this position.

The ${ }^{3} J_{\mathrm{HNH} \alpha}$ coupling constants (Fig. 2) measured for the peptides are characteristic of either extended or unfolded states. Nevertheless, an averaging over at least two different conformations cannot be excluded. With analogues $\mathbf{I}$ and III, the ${ }^{3} \mathrm{~J}_{\mathrm{HNH} \alpha}$ coupling constants recorded for the L-Igl ${ }^{2}$ and $\mathrm{Phe}^{3}$ neighbouring residues, (6.4 and 9.7; 7.4 and 9.7 for peptides I and III, respectively) suggest $\beta$-turn at position 2,3 (numbers correspond to the two central residues of the $\beta$-turn). This is the consequence of the steric hindrance imposed by the $\beta$-turn, which causes that the corner residues at positions $i+1$ and $i+2$ of the $\beta$-turn are characterized by low and high the ${ }^{3} \mathrm{~J}_{\mathrm{HNH} \alpha}$ coupling constant values, respectively.

It is known that proline $\phi$ dihedral angle is relatively fixed at about $-60^{\circ}$. The proline ring has also a significant effect on $\psi$ dihedral angle resulting in two minima, $-40^{\circ}$ and $150^{\circ}$ [45]. In tun, the 
high value of ${ }^{3} \mathrm{~J}_{\mathrm{HNH} \alpha}$ coupling constant for $\mathrm{Arg}^{8}$ of analogue $\mathbf{I}(10.2 \mathrm{~Hz})$ corresponds to dihedral angle $\phi$ in the range of $-140^{\circ} \div-100^{\circ}[46,47]$. Bearing all these facts in mind, we can expect one of the three types of $\beta$-turns, $\beta \mathrm{I}: \phi_{\mathrm{i}+1}=-60, \psi_{\mathrm{i}+1}=-30, \phi_{\mathrm{i}+2}=-90, \psi_{\mathrm{i}+2}=0, \beta \mathrm{II}: \phi_{\mathrm{i}+1}=-60, \psi_{\mathrm{i}+1}=120, \phi_{\mathrm{i}+2}=80$, $\psi_{\mathrm{i}+2}=0 \quad \beta$ VIII-turn $\left(\phi_{\mathrm{i}+1}=-60, \psi_{\mathrm{i}+1}=-30, \phi_{\mathrm{i}+2}=-120, \psi_{\mathrm{i}+2}=120\right)[48]$ in the fragment $\mathrm{Cys}^{6}-\mathrm{Pro}^{7}-\mathrm{Arg}^{8}-\mathrm{Gly}^{9}$ of compound $\mathbf{I}$.

The temperature coefficients of the amide protons (Fig. 2) of $\mathrm{L}-\mathrm{Igl}^{2}, \mathrm{Arg}^{8}$ and $\mathrm{Gly}^{9}$ of $[\mathrm{L}-$ $\left.\operatorname{Igl}^{2}\right]$ AVP (I), D-Igl $1^{2}, \mathrm{Phe}^{3}$ and Gly ${ }^{9}$ of $\left[\mathrm{D}-\operatorname{Igl}^{2}\right]$ AVP (II), $\mathrm{Arg}^{8}$ and Gly of $\left[\mathrm{Mpa}^{1} \mathrm{~L}^{9}-\mathrm{Igl}^{2}\right] \mathrm{AVP}$ (III) and $\mathrm{Gln}^{4}$ of $\left[\mathrm{Mpa}^{1}\right.$,D-Igl $\left.{ }^{2}\right] \mathrm{AVP}(\mathbf{I V})$ were in the range of $-5<\Delta \delta / \Delta \mathrm{T}<-3 \mathrm{ppb} / \mathrm{K}$, indicating weak intramolecular and/or solute-solvent hydrogen bonds. However, the shielding of the amide protons from solvent exchange might be dominated by interaction between the peptide and micelle, rather than by intramolecular interactions [49]. In the case of $\mathrm{Gln}^{4}$ of compound III, the amide proton HN of $\mathrm{Gln}^{4}$ is probably hydrogen bonding up to $30^{\circ} \mathrm{C}$, but it becomes broken at higher temperatures, which is manifested by higher tilt of temperature gradient in the range of $30-50^{\circ} \mathrm{C}$. Similar effect was observed for mesotocin in SDS/water solution [38].

The temperature coefficients of the remaining amide protons were more negative than -5 $\mathrm{ppb} / \mathrm{K}$, which rather excludes stable hydrogen bonds.

Conformational analysis of the calculated structures. The structures of the peptides are shown in Figure 3 and are aligned to their mostly populated conformations using backbone atoms of the cyclic part of the molecules. The RMSD values for the ensemble of the structures are $0.288,0.276$, 0.226 and $0.195 \AA$ for backbone atoms of cyclic part of analogues I, II, III and IV, respectively.

The common conformational feature (Tab. 1) of all the analogues is a $\beta$-turn at position 2,3. In the analogues $\mathbf{I}$ and III, this $\beta$-turn is stabilized by the $\mathrm{HN}^{4}-\mathrm{CO}^{1}$ hydrogen bond. In turn, in the case of analogues II and IV, the $\beta$-turn at position 2,3 is not tight enough and the $\mathrm{Gln}^{4} \mathrm{HN}$ amide proton is not hydrogen bonding. Three of the analogues, namely II, III and IV create additional $\beta$ - 
turn at position 3,4. Nevertheless, this $\beta$-turn is distorted. Therefore, their existence may not result directly from NMR data.

The analogue III, as the only one, adopts a $\beta$-turn at position 4,5 . This $\beta$-turn is not closed by hydrogen bond, which is a consequence of distortion of either the $\psi_{4}$ or $\phi_{5}$ dihedral angles. In addition, an inverse $\gamma$-turn over the Pro $^{7}$ was found for compounds III. In turn, the C-terminus of the peptide $\mathbf{I}$ is involved in a $\beta$-turn in the $\mathrm{Cys}^{6}-\mathrm{Gly}^{9}$ fragment. While simultaneously, it assumes a hydrogen-bonded $\beta$ I- or $\beta$ III-turn at positions 6,7 .

The averaged radii of gyration $(\mathrm{Rg})$ (Tab. 1) calculated with all of the heavy atoms for each analogue indicate that the conformation of the analogue II is noticeably more extended than the remaining analogues, this being due to a more outstretched structure of the acyclic part of the molecule. The differences in the Rg values obtained for the cyclic part of each analogue are comparable, indicating similar sizes of the tocin rings.

Conformation of the aromatic side chains. All the structures were submitted to statistical study of relative orientation of the $\mathrm{Igl} / \mathrm{D}-\mathrm{Igl}^{2}$ and $\mathrm{Phe}^{3}$ aromatic side chains. It is clearly seen (Fig. 4a) that the preferred rotamer about the $\chi_{1}$ torsion angle of $\operatorname{Igl}$ is gauche(-) for both analogues with L-Igl, I and III, and either trans or gauche(+) for II and IV, respectively. A relationship has been established between the flat angle between the planes of aromatic rings $\left(F_{\text {Igl-Phe }}\right)$ and a dihedral angle between two planes, where the former is determined by the mass centre of aromatic part of Igl/D-Igl ${ }^{2}, \mathrm{C} \alpha$ of Igl/D-Igl ${ }^{2}$ and $\mathrm{C} \alpha$ of $\mathrm{Phe}^{3}$, whereas the latter by $\mathrm{C} \alpha$ of $\mathrm{Igl} / \mathrm{D}-\mathrm{Igl}^{2}, \mathrm{C} \alpha$ of $\mathrm{Phe}^{3}$ and the centre of mass of aromatic ring of $\mathrm{Phe}^{3}\left(D_{\text {Igl-Phe }}\right)$ (Fig. $\left.4 \mathrm{~b}\right)$. Taking into account the flat angle, $F_{\text {Igl-Phe, }}$ the structure of all the peptides, with the exception of analogue $\mathbf{I V}$, can be divided into two groups based on different orientation of the $\mathrm{Phe}^{3}$ side chain caused by changes of its $\chi_{2}$ dihedral angle (Fig. $4 \mathrm{a}$ ). In turn, the dihedral angle values, $D_{\text {Igl-Phe }}$, are clustered about horizontal lines, one for each peptide, $D_{\text {Igl-Phe }}=$ $15^{\circ}, 85^{\circ}, 13^{\circ}$ and $65^{\circ}$ for analogues I, II, III and IV, respectively, where the angles correspond to average values of $D_{\text {Igl-Phe. }}$ As seen, the $D_{\text {Igl-Phe }}$ values are noticeably greater for analogues modified 
with the D enantiomer of Igl. The differences in the $D_{\text {Igl-Phe }}$ values are most of all the consequence of the change of Igl configuration from L to D, which evidently alters the side chain orientation.

\section{Radial distribution functions and hydration numbers for the AVP analogues in SDS micelle.}

During molecular dynamics simulations, the peptides diffusing from the hydrophobic core of the SDS micelle to the interface to adopt energetically more favorable conformation. The position of the peptides on the micellar surface becomes fixed after ca. 2 ns of MD. Thereafter, the peptides remain bound to the interface for a further 4 ns of LES simulations. Figure 5 presents the structures of the peptides with the highest statistical weight binding with the SDS micelle. The peptide-micelle interactions were analyzed by the radial distribution function (RDF) values for all the amino acids in each peptide (Figs. 6 and 7). In addition, the hydration numbers were calculated to investigate interaction with water molecules (Tab. 2).

In each peptide the aromatic residues, $\operatorname{Igl} / \mathrm{D}-\operatorname{Igl}^{2}$ and $\mathrm{Phe}^{3}$ are deeply immersed into the hydrophobic micelle core as additionally confirmed by low hydration numbers calculated for their side chains. Nevertheless, the backbone oxygen atoms of both D-Igl ${ }^{2}$ and $\mathrm{Phe}^{3}$ in compound IV are strongly hydrated in contrast to the remaining peptides.

The positively charged centre on the Arg side chain shows the tendency to be associated with sulfate ions of SDS and at the same time, it is located near the hydrophobic part of the micelle. In turn, the oxygen atom of $\mathrm{Arg}^{8}$ is exposed to the aqueous environment in each case. The analogues I and II possess also the positively charged N-terminus, and consequently the stronger interactions between the N-terminus and negatively charged sulfate head groups of the SDS micelle is noticed than for the deamino analogues (Fig. 6). In turn, in the deamino analogues, III and IV, the Pro ${ }^{7}$ side chain clearly penetrates interior of the SDS micelle (Fig. 7). Moreover, the hydration numbers (Tab. 2) indicate that also the oxygen atom of Pro is embedded into the hydrophobic micelle core. The common feature of the deamino analogues are also high hydration number calculated for a backbone oxygen atom of $\mathrm{Gln}^{4}$, which indicates that it is exposed to the aqueous phase. In the case 
of peptide III, the $\mathrm{Gln}^{4}$ side chain is also characterized by a high hydration number.

The side chains of residues 1 and 6 of the D-Igl-modified analogues, II and IV, are evidently more deeply embedded into the micelle core than in the remaining ones and consequently disulfide bridges of both peptides are hidden from the aqueous phase.

Biological relevance of the modifications. It becomes clear that all the analogues exhibit the tendency to adopt $\beta$-turns at positions 2,3 and/or 3,4, which is characteristic of oxytocin-like peptides [50]. Thus, the high affinity of the analogues to the OT receptors might be due to these reverse structures. Moreover, it seems likely that the strong $\pi-\pi$ interactions between aromatic side chains of the vasopressin-like peptides and the aromatic residue cluster, located in TM6 OT and $\mathrm{V}_{1 \mathrm{a}}$ receptor, might be responsible for antagonistic properties [51]. It is also known that the amino acid at position 2 of a ligand plays a key role in the antagonistic effect. Insertion of a bulky lipophilic Damino acid at this position enhances often antioxytocic properties [14], and at the same time alters the side chain orientation. Consequently, mutual arrangement of the side chains of neighbouring residues at positions 2 and 3 undergoes changes. A closer examination of the indanylglycine $\chi_{1}$ space angle suggests that the common feature of analogues I and III is the gauche(-) conformation of the Igl side chain, which may be crucial for selectivity in this series of analogues, given that both analogues exhibit only antiuterotonic activity. On the other hand, a comparison of the flat $F_{\text {Igl-Phe }}$ and dihedral $D_{\text {Igl-Phe }}$ angles (see Conformation of the aromatic side chains section) of the analogues has shown that the latter adopts greater values for analogues II and IV, which are blockers of both the OT and $\mathrm{V}_{1 \mathrm{a}}$ receptors. A similar tendency was reported for AVP analogues modified with Nmethylpenylalanine enantiomers at positions 2 and 3 [52].

Earlier investigations have shown that replacement of $\mathrm{Gln}^{4}$ in AVP reduced significantly the affinity toward $\mathrm{V}_{1 \mathrm{a}}$ receptors $[53,54]$. Moreover, the hydrogen bond between the $\mathrm{Thr}^{7.38} 333$ hydroxyl of $\mathrm{V}_{1 \mathrm{a}}$ receptor and the carboxamide of the AVP $\mathrm{Gln}^{4}$ was found to be important for AVP binding [55]. In addition, $\operatorname{Thr}^{7.38} 333$ was proposed as the residue controlling the $\mathrm{V}_{1 \mathrm{a}} / \mathrm{V}_{2}$ binding selectivity 
for vasopressin antagonists [56]. Hence, the orientation of $\mathrm{Gln}^{4}$ side chain of a ligand seems to be important for $\mathrm{V}_{1 \mathrm{a}}$ receptor affinity. In each of the peptides studied, the $\mathrm{Gln}^{4}$ side chain is folded back over the ring moiety. However, it lies on the opposite face of the tocin moiety in analogues with $\mathrm{L}$ and $\mathrm{D}$ enantiomers of Igl, which can additionally explain their different activities towards the $\mathrm{V}_{1 \mathrm{a}}$ receptor.

\section{CONCLUSIONS}

The affinity of the vasopressin analogues to respective receptors is a consequence of their structure and conformation. For this reason, a correlation between the structure and conformation can provide valuable data to design new analogues with appropriate biological activity. However, short peptides, such as vasopressin, usually adopt unstable conformation and exist in many conformations at equilibrium. Multiple conformations occurring in a dynamic exchange produce averaged NMR parameters, which hamper unequivocal conformational analysis. Hence, all the available NMR data should be examined with caution.

The primary purpose of substitution of indanylglycine (Igl) at position 2 of the AVP analogues was to reduce their flexibility and to change pharmacological profile of the peptides. Moreover, using the SDS micelle in the NMR studies may additionally restrict conformational freedom of the peptides and probably induces a conformation, which is supposed to be bound to the receptor.

In summary, the new AVP analogues should be designed in such a way, as to preserve specific conformation of a peptide and the proper mutual arrangement of the side chains. Moreover, it should be remembered that the structurally restricted modifications reduce the flexibility of a peptide thus enabling a more precise conformational analysis to be made. Introduction of a D-amino acid in the second position of the AVP analogues changes the side chain orientation and enforces the possibility of $\beta$-turn formation in a 1-4 fragment, which is characteristic of oxytocin-like peptides. Furthermore, the specific orientation of the side chains at positions 2 and 3 is important for 
antagonistic properties. In addition, the $\mathrm{Gln}^{4}$ side chain arrangement seems to be crucial for $\mathrm{V}_{1 \mathrm{a}}$ receptor affinity.

Acknowledgements. This work was supported by the Polish Scientific Research Committee Grant No. N N204 181736 . The calculations were carried out in the Academic Computer Centre (TASK) in Gdańsk, Poland.

Appendix A. Supplementary materials. Supplementary data associated with this article can be found, in the online version.

\section{REFERENCES}

[1] M. Barlow M., Vasopressin, Emerg. Med. 14 (2002) 304-314.

[2] M. Birnbaumer, Vasopressin receptors, Trends Endocrinol. Metab. 11 (2000) 406-410.

[3] S. Jard, R.C. Gaillard, G. Guillon, J. Marie, P. Schoenenberg, A.F. Muller, M. Manning, W.H. Sawyer, Vasopressin antagonists allow demonstration of a novel type of vasopressin receptor in the rat adenohypophysis, Mol. Pharmacol. 30 (1986) 171-177.

[4] Z. Wang, L.J. Young, G.J. De Vries, T.R. Insel, Voles and vasopressin: a review of molecular, cellular and behavioral studies of pair bonding and paternal behaviors, Prog. Brain Res. 119 (1998) 483-499.

[5] C. Barberis, B. Mouillac, T. Durroux, Structural bases of vasopressin/oxytocin receptor function, J. Endocrinol. 156 (1998) 223-229.

[6] C.J. Newschaffer, L.A. Croen, J. Daniels, E. Giarelli, J.K. Grether, S.E. Levy, Mandell D.S., Miller L.A., J. Pinto-Martin, J. Reaven, A.M. Reynolds, C.E. Rice, D. Schendel, G.C. Windham, The epidemiology of autism spectrum disrorders. Annu. Rev. Public Health 28 (2007) 235-258.

[7] T.R. Insel, D.J. O'Brien, J.F. Leckman, Oxytocin, vasopressin, and autism: is there a 
connection? Biol. Psychiatry 45 (1999) 145-157.

[8] K. Palczewski, T. Kumasaka, T. Hori, C.A. Behnke, H. Motoshima, B.A. Fox, I. Le Trong, D.C. Teller, T. Okada, R.E. Stenkamp, M. Yamamoto, M. Miyamoto, Crystal structure of rhodopsin: a G protein-coupled receptor, Science 289 (2000) 739-745.

[9] R.J. Schwayzer, In search of the 'bio-active conformation' - is it induced by the target cell membrane? Mol. Recog. 8 (1995) 3-8.

[10] D.F. Mierke, C. Giragossian, Peptide hormone binding to G-protein-coupled receptors: structural characterization via NMR techniques, Med. Res. Rev. 21 (2001) 450-471.

[11] J. Hlavacek J., Important structural modifications. Noncoded amino acid. In Handbook of Neurohypophyseal Hormone Analogs, (Jošt K., Lebl M., Brtnik F., eds.), vol. 1, Part 2, CRC Press Inc., Boca Raton, Florida, (1987) 109-129.

[12] V.J. Hruby, M.S. Chow, D.D. Smith, Conformational and structural considerations in oxytocin-receptor binding and biological activity, Annu. Rev. Pharmacol. Toxicol. 30 (1990) 501-534.

[13] K. Bakos, J. Havass, F. Fülöp, L. Gera, J.M. Stewart, G. Falkay, G.K. Tóth, Synthesis and receptor binding of oxytocin analogs containing conformationally restricted amino acids, Lett. Pept. Sci. 8 (2002) 35-40.

[14] B. Jójárt, Á. Márki, Comparative study of eight oxytocin antagonists by simulated annealing, J Mol. Model. 12 (2006) 823-828.

[15] R. Sankararamakrishnan, Recognition of GPCRs by peptide ligands and membrane compartments theory: structural studies of endogenous peptide hormones in membrane environment, Biosci. Rep. 26 (2006) 131-158.

[16] L. Gera, J.M. Stewart, A new class of bradykinin antagonists containing indanylglycine, Immunopharmacol. 33 (1996) 174-177.

[17] W.H. Sawyer, M. Acosta, M. Manning, Structural changes in the arginine vasopressin molecule that prolong its antidiuretic action, Endocrinology 95 (1974) 140-149. 
[18] Z. Grzonka, F. Kasprzykowski, L. Lubkowska, K. Darlak, T.A. Hahn, A.F. Spatola, In vitro degradation of some arginine-vasopressin analogs by homogenates of rat kidney, liver, and serum, Peptide Res. 4 (1991) 270-274.

[19] A. Kwiatkowska, M. Śleszyńska, I. Derdowska, A. Prahl, D. Sobolewski, L. Borovickova, J. Slaninowa, B. Lamek, Novel analogu es of arginine vasopressin containing $\alpha-2$ indanylglycine enantiomers in position 2, J. Pept. Sci., 16 (2010) 15-20.

[20] C. Cosola, M. Albrizio, A.C. Guaricci, M.A. De Salvia, A. Zarrilli, R.L. Sciorsci, R. Minoia, Opioid agonist/antagonist effect of naloxone in modulating rabbit jejunum contractility in vitro, J. Physiol. Pharm. 57 (2006) 439-449.

[21] A. Bax, R. Freeman, Enhanced NMR resolution by restricting the effective sample volume, J. Magn. Reson. 65 (1985) 355-360.

[22] M. Rance, O.W. Sorenson, G. Bodenhausen, G. Wagner, R.R. Ernst, K. Wüthrich, Improved spectral resolution in cosy ${ }^{1} \mathrm{H}$ NMR spectra of proteins via double quantum filtering, Biochem. Biophys. Res. Commun. 117 (1983) 479-485.

[23] A. Kumar, R.R. Ernst, K. Wüthrich, A two-dimensional nuclear Overhauser enhancement (2D NOE) experiment for the elucidation of complete proton-proton cross relaxation networks in biological macromolecules, Biochim. Biophys. Res. Commun. 95 (1980) 1-10.

[24] A.A. Bothner-By, R.L. Stephens, J.M Lee, C.D. Warren, R.W. Jeanloz, Structure determination of a tetrasaccharide: Transient nuclear Overhauser effects in the rotating frame. JACS 106 (1980) 811-813.

[25] A. Bax, D.G. Davis, Practical aspects of two-dimensional transverse NOE spectroscopy, J. Magn. Reson. 63 (1985) 207-213.

[26] A.G. Palmer, J. Cavanagh, P.E. Wright, M. Rance, Sensitivity improvement in proton-detected two-dimensional heteronuclear correlation spectroscopy, J. Magn. Reson. 93 (1991) 151-170.

[27] L.E. Kay, P. Keifer, T. Saarinen, Pure absorption gradient enhanced heteronuclear single quantum correlation spectroscopy with improved sensitivity, JACS 114 (1992) 10663-10665. 
[28] J. Schleucher, M. Schwendinger, M. Sattler, P. Schmidt, O. Schedletzky, S.J. Glaser, O.W. Sorensen, C. Griesinger, A general enhancement scheme in heteronuclear multidimensional NMR employing pulsed field gradients, J. Biomol. NMR 4 (1994) 301-306.

CC. D.S. Wishart, C.G. Bigam, A. Holm, R.S. Hodges, B.D. Sykes, 1H, 13C and 15N random coil NMR chemical shifts of the common amino acids. I. Investigations of nearest-neighbor effects, J. Biomol. NMR 5 (1995) 67-81.

[30] C. Bartles, T. Xia, M. Billeter, P. Günter, K. Wüthrich, The program XEASY for the computer-supported NMR spectral analysis of biological macromolecules, J. Biomol. NMR 5 (1995) 1-10.

[31] M. Groth, J. Malicka, C. Czaplewski, S. Ołdziej, L. Łankiewicz, W. Wiczk, A. Liwo, Maximum entropy approach to the determination of solution conformation of flexible polypeptides by global conformational analysis and NMR spectroscopy - Application to $\mathrm{DNS}^{1}-\mathrm{c}-\left[\mathrm{D}-\mathrm{A}_{2} \mathrm{bu}^{2}, \operatorname{Trp}^{4}, \mathrm{Leu}^{5}\right]-$ enkephalin and DNS ${ }^{1}-\mathrm{c}-\left[\mathrm{d}-\mathrm{A}_{2} \mathrm{bu}^{2}, \operatorname{Trp}^{4}, \mathrm{D}-\mathrm{Leu}^{5}\right]$ enkephalin, J. Biomol. NMR 15 (1999) 315-330.

[32] D.A. Case, T.A. Darden, T.E. Cheatham, III, C.L. Simmerling, J. Wang, R.E. Duke, R. Luo, K.M. Merz, D.A. Pearlman, M. Crowley, R.C. Walker, W. Zhang, B. Wang, S. Hayik, A. Roitberg, G. Seabra, K.F. Wong, F. Paesani, X. Wu, S. Brozell, V. Tsui, H. Gohlke, L. Yang, C. Tan, J. Mongan, V. Hornak, G. Cui, P. Beroza, D.H. Mathews, C. Schafmeister, W.S. Ross, P.A. Kollman, AMBER 9, University of California, San Francisco, 2006.

[33] F.H. Allen, W.D.S. Motherwell, Applications of the Cambridge Structural Database in organic chemistry and crystal chemistry, Acta Cryst. B58 (2002) 407-422.

[34] M.W. Schmidt, K.K. Baldridge, J.A. Boatz, S.T. Elbert, M.S. Gordon, J.H. Jensen, S. Koseki, N. Matsunaga, K.A. Nguyen, S. Su, T.L. Windus, M. Dupuis, JA. Montgomery, General atomic and molecular electronic structure system, J. Comput. Chem. 14 (1993) 1347-1363.

[35] C.I. Bayly, P. Cieplak, W.D. Cornell, P.A. Kollman, A well-behaved electrostatic potential based method using charge restraints for deriving atomic charges: the RESP model, J. Phys. 
Chem. 97 (1993) 10269-10280.

[36] K.J. Schweighofer, U. Essman, M. Berkowitz, Simulation of sodium dodecyl sulfate at the water-vapor and water-carbon tetrachloride interfaces at low surface coverage, J. Phys. Chem. B. 101 (1997) 3793-3799.

[37] C.D. Bruce, M.L. Berkowitz, L. Perera, M.D.E. Forbes, Molecular dynamics simulation of sodium dodecyl sulfate micelle in water: micellar structural characteristics and counterion distribution. J. Phys. Chem. B. 106 (2002) 3788-3793.

[38] S. Rodziewicz-Motowidło, E. Sikorska, M. Oleszczuk, C. Czaplewski, Conformational studies of vasopressin and mesotocin using NMR spectroscopy and molecular modeling methods. Part II: Studies in the SDS micelle, J. Pept. Sci., 14 (2008) 85-96.

[39] X. Cheng, V. Hornak, C. Simmerling, Improved conformational sampling through an efficient combination of mean-field simulation approaches. J. Phys. Chem. B 108 (2004) 426-437.

[40] R. Meadows, C.B. Post, B.A. Luxon, D.G. Gorenstein, MORASS 2.1 Program, Purdue University, W. Lafayette, 1994.

[41] V.F. Bystrov, Spin-spin coupling and the conformational states of peptide system, Progr. NMR Spectrosc. 10 (1976) 41-81.

[42] C. Yu, T.H. Yang, C.J. Yeh, L.C. Chuang, Combined use of NMR, distance geometry, and retrained energy minimization for the conformational analysis of 8-lysinevasopressin, Can. J. Chem. 70 (1992) 1950-1955.

[43] R. Koradi, M. Billeter, K. Wüthrich, K., MOLMOL: a program for display and analysis of macromolecular structures, J. Mol. Graphics 14 (1996) 52-55.

[44] H.J. Dyson, M. Rance, R.A. Houghten, R.A. Lerner, P.E. Wright, Folding of immunogenic peptide fragments of proteins in water solution. I Sequence requirements for the formation of a reverse turn, J. Mol. Biol. 201 (1988) 161-200.

[45] M.P. Wiliamson, The structure and function of proline-rich regions in proteins, Biochem J. 297 (1994) 249-260. 
[46] A. Pardi, M. Billeter, K. Wüthrich, Calibration of the angular-dependence of the amide proton-C-alpha proton coupling-constants, ${ }^{3} \mathrm{~J}_{\mathrm{HNH} \alpha}$, in a globular protein - use of ${ }^{3} \mathrm{~J}_{\mathrm{HNH} \alpha}$ for identification of helical secondary structure, J. Mol. Biol. 180 (1984) 741-751.

[47] M. Eberstadt, G. Gemmecker, D.F. Mierke, H. Kessler, Scalar Coupling Constants - Their Analysis and Their Application for the Elucidation of Structures, Angew. Hem. Int. Ed. Engl. 34 (1995) 1671-1695.

[48] P.N. Lewis, F.A. Momany, H.A. Scheraga, Chain reversals in proteins, Biochim. Biophys. Acta 303 (1973) 211-229.

[49] S. De Luca, R. Ragone, C. Bracco, G. Digilio, L. Aloj, D. Tesauro, M. Saviano, C. Pedone, G. Morelli, A cyclic CCK8 analogue selective for the cholecystokin type A receptor: design, synthesis, NMR structure and binding measurements. ChemBioChem. 4 (2003) 1176-1187.

[50] A. Liwo, A. Tempczyk, S. Ołdziej, M.D. Shenderovich, V.J. Hruby, S. Talluri, J. Ciarkowski, F. Kasprzykowski, L. Łankiewicz, Z. Grzonka, Exploration of the conformational space of oxytocin and arginine-vasopressin using the electrostatically driven Monte Carlo and molecular dynamics methods, Biopolymers 38 (1996) 157-175.

[51] M.J. Ślusarz, E. Sikorska, R. Ślusarz, J. Ciarkowski, Molecular docking-based study of vasopressin analogues modified at positions 2 and 3 with N-methylphenylalanine: influence on receptor-bound conformations and interactions with vasopressin and oxytocin receptors, J. Med. Chem. 49 (2006) 2463-2469.

[52] E. Sikorska, M.J. Ślusarz, B. Lammek, Conformational studies of vasopressin analogues modified with N-methylphenylalanine enantiomers in dimethyl sulfoxide solution, Biopolymers 82 (2006) 603-614.

[53] W.H. Sawyer, M. Acosta, L. Balaspiri, J. Judd, M. Manning, Structural changes in the arginine vasopressin molecule that enhance antidiuretic activity and specificity, Endocrinology 94 (1974) 1106-1115. 
[54] D. Gillessen, V. du Vigneaud, The synthesis and pharmacological properties of 4-decarboxamide-8-1ysinevasopressin, 5- decarboxamide-8-1ysinevasopressin, and their 1-deamino analogs, J. Biol. Chem. 242 (1967) 4806-4812.

[55] M.J. Ślusarz, A. Giełdoń, R. Ślusarz, J. Ciarkowski, Analysis of interactions responsible for vasopressin binding to human neurohyphophyseal hormone receptors - molecular dynamics study of the activated receptor-vasopressin-G $\alpha$ systems, J. Pept. Sci. 12 (2006) 180-189.

[56] N. Cotte, M.N. Balestre, A. Aumelas, E. Mahé, S. Phalipou, D. Morin, M. Hibert, M. Manning, T. Durroux, C. Barberis, B. Mouillac, Conserved aromatic residues in the transmembrane region VI of the V1a vasopressin receptor differentiate agonist vs. antagonist ligand binding, Eur. J. Biochem. 267 (2000) 4253-4263. 


\section{Figure captions}

Figure 1. (A) 2- $\alpha$-Indanylglycine (Igl) and (B) 3-mercaptopropionic acid (Mpa).

Figure 2. The NOE effects corresponding to the interproton distances, ${ }^{3} \mathrm{~J}_{\mathrm{HNH} \alpha}$ coupling constants and the temperature coefficients of the backbone amide atoms of (A) [L-Igl $\left.{ }^{2}\right]$ AVP (I), (B) [D-Igl $\left.{ }^{2}\right]$ AVP (II), (C) $\left[\mathrm{Mpa}^{1}, \mathrm{~L}_{-\mathrm{Igl}^{2}}\right] \mathrm{AVP}\left(\right.$ III) and (D) $\left[\mathrm{Mpa}^{1}, \mathrm{D}-\mathrm{Igl}{ }^{2}\right] \mathrm{AVP}(\mathbf{I V})$.

Figure 3. Stereoview showing the conformational ensembles of (A) [L-Igl $\left.{ }^{2}\right] A V P(I),(B)[D-$ $\left.\operatorname{Igl}^{2}\right] \operatorname{AVP}(\mathbf{I I}),(\mathbf{C})\left[\mathrm{Mpa}^{1}, \mathrm{~L}-\operatorname{Igl}^{2}\right] \mathrm{AVP}$ (III) and (D) $\left[\mathrm{Mpa}^{1}, \mathrm{D}-\operatorname{Igl}^{2}\right] \mathrm{AVP}(\mathbf{I V})$ obtained by fitting the statistical weights of MD-generated conformations. $\mathrm{RMSD}=0.288,0.276,0.226$ and 0.195 for backbone atoms of cyclic part, respectively.

Figure 4. (A) Scatter plots of the side chain dihedral angles $\left(\chi_{1}: \mathrm{N}-\mathrm{C} \alpha-\mathrm{C} \beta-\mathrm{C} \gamma 1\right.$ of $\operatorname{Igl} / \mathrm{D}-\mathrm{Ig} 1^{2}, \chi_{1}: \mathrm{N}-$ $\mathrm{C} \alpha-\mathrm{C} \beta-\mathrm{C} \gamma$ and $\chi_{2}: \mathrm{C} \alpha-\mathrm{C} \beta-\mathrm{C} \gamma-\mathrm{C} \delta 1$ of $\mathrm{Phe}^{3}$ ) of aromatic residues of [L-Igl $\left.{ }^{2}\right] \mathrm{AVP}$ (I), [D-Igl $\left.{ }^{2}\right] \mathrm{AVP}$ (II), $\left[\mathrm{Mpa}^{1}, \mathrm{~L}-\mathrm{Igl}^{2}\right] \mathrm{AVP}$ (III) and $\left[\mathrm{Mpa}^{1}, \mathrm{D}-\mathrm{Igl}^{2}\right] \mathrm{AVP}$ (IV) and (B) the relationship between the flat angle between the planes of aromatic rings $\left(F_{\text {Igl-Phe }}\right)$ and dihedral angle between two planes, where the former is determined by the centre of mass of aromatic part of $\operatorname{Igl} / \mathrm{D}-\operatorname{Igl}^{2}, \mathrm{C} \alpha$ of $\operatorname{Igl} / \mathrm{D}-\operatorname{Igl}{ }^{2}$ and $\mathrm{C} \alpha$ of $\mathrm{Phe}{ }^{3}$, whereas the latter by $\mathrm{C} \alpha$ of $\operatorname{Igl} / \mathrm{D}-\mathrm{Igl}^{2}, \mathrm{C} \alpha$ of $\mathrm{Phe}^{3}$ and the centre of mass of aromatic ring of $\mathrm{Phe}^{3}\left(D_{\text {Igl-Phe }}\right)$.

Figure 5. The complexes of the structure with the highest statistical weight of (A) [L-Igl'] AVP (I), (B) $\left[\mathrm{D}-\mathrm{Igl}^{2}\right] \mathrm{AVP}$ (II), (C) $\left[\mathrm{Mpa}^{1}, \mathrm{~L}-\mathrm{Igl}^{2}\right] \mathrm{AVP}$ (III) and (D) $\left[\mathrm{Mpa}^{1}, \mathrm{D}-\mathrm{Igl}^{2}\right] \mathrm{AVP}$ (IV) with SDS micelles. The positively charged residues are displayed in cyan, the uncharged polar residue in blue, the hydrophobic residues in red. Additionally, the sulfur atoms are presented in yellow.

Figure 6. Radial distribution functions $\mathrm{g}(\mathrm{r})$ between the sulfate head groups on SDS micelle and the side chain (heavy atoms) of each residue. The r parameter defines the distance in $\AA$.

Figure 7. Radial distribution functions $g(r)$ between the micelle core and the side chain (heavy atoms) of each residue. The r parameter defines the distance in Å. Note different scale for residues 3 and 7. 
A

B

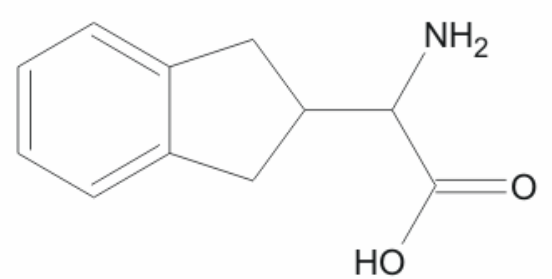

$\overbrace{\mathrm{OH}}^{\mathrm{O}}$ 
A

123456789

$$
\begin{aligned}
& d_{\alpha \mathrm{N}}(i, i) \\
& d_{\beta \mathrm{N}}(i, i)
\end{aligned}
$$

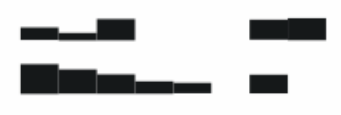

$d_{\mathrm{NN}}(i, i+1)$

$d_{\alpha \mathrm{N}}(i, i+1)$

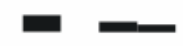

$d_{\beta \mathrm{N}}(i, i+1)$

口

$d_{\alpha \mathrm{N}}(i, i+2)$

$d_{\beta \mathrm{N}}(i, i+2)$

$d_{\alpha \mathrm{N}}(i, i+3)$

$d_{\beta \mathrm{N}}(i, i+3)$

${ }^{3} \mathrm{~J}_{\mathrm{HNH} \alpha}$

$649.76969 \quad 1025.4$

$-\Delta \delta / \Delta \mathrm{T}$

$335.1527 .05 .1 \quad 3939$

C

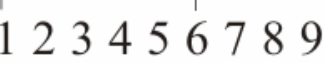

$$
\begin{aligned}
& d_{\alpha \mathrm{N}}(i, i) \\
& d_{\beta \mathrm{N}}(i, i)
\end{aligned}
$$

$d_{\mathrm{NN}}(i, i+1)$

$d_{\alpha \mathrm{N}}(i, i+1)$

$d_{\beta \mathrm{N}}(i, i+1)$

$d_{\alpha \mathrm{N}}(i, i+2)$

$d_{\beta \mathrm{N}}(i, i+2)$

$d_{\alpha \mathrm{N}}(i, i+3)$

$d_{\beta \mathrm{N}}(i, i+3)$

${ }^{3} \mathrm{~J}_{\mathrm{HNH} \alpha}$

7.49 .7

7.75 .6

$-\Delta \delta / \Delta \mathrm{T}$

8952637.87 .0
B

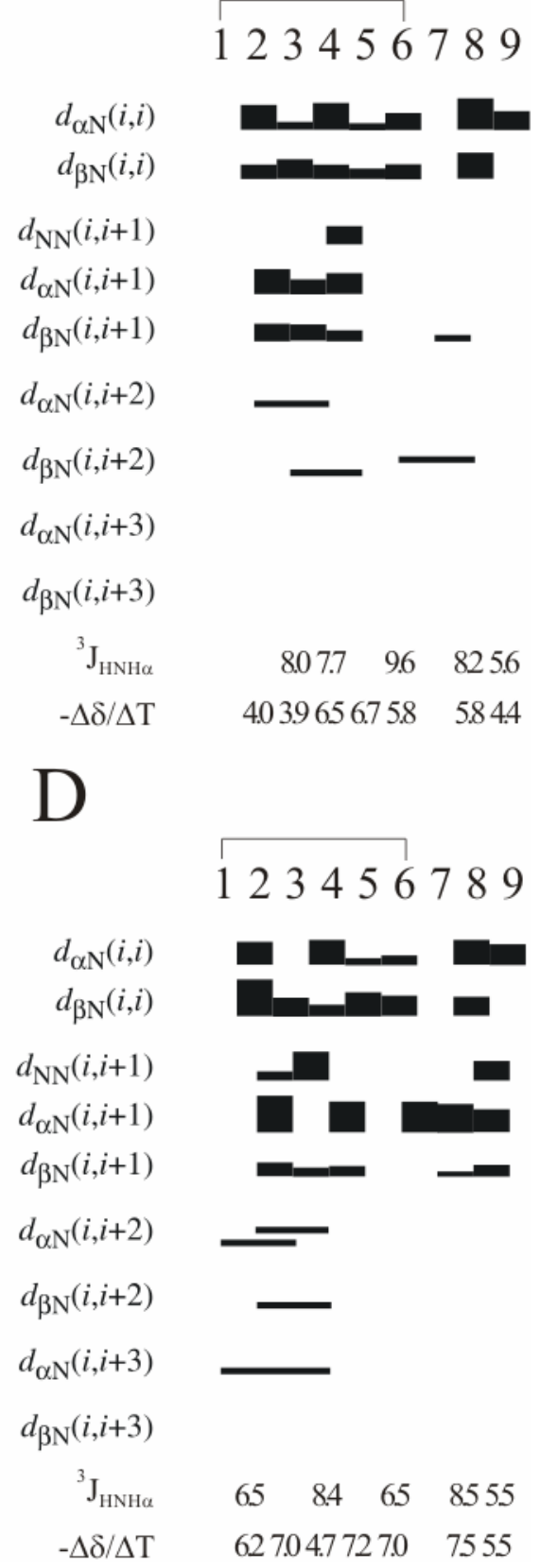



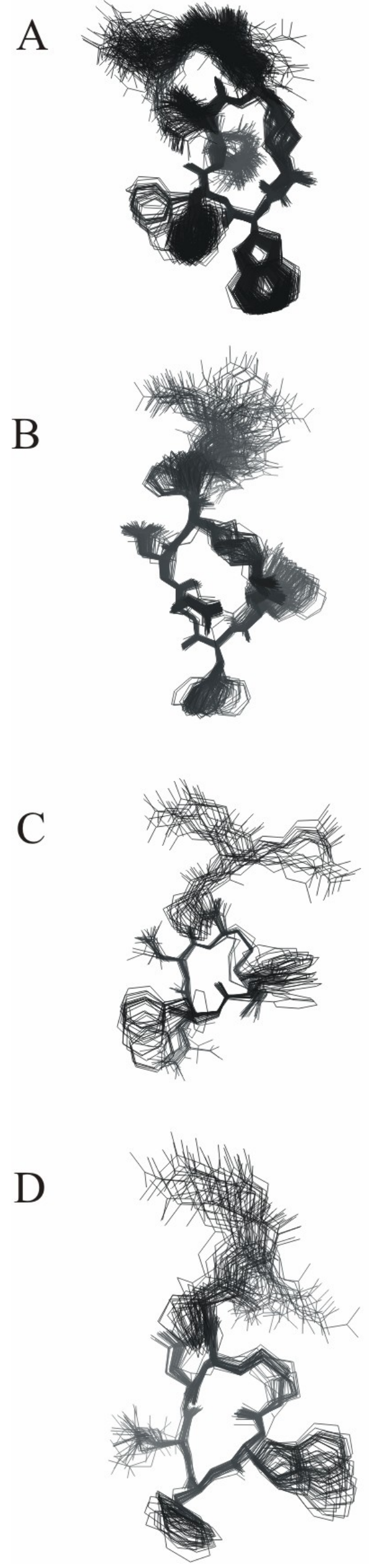
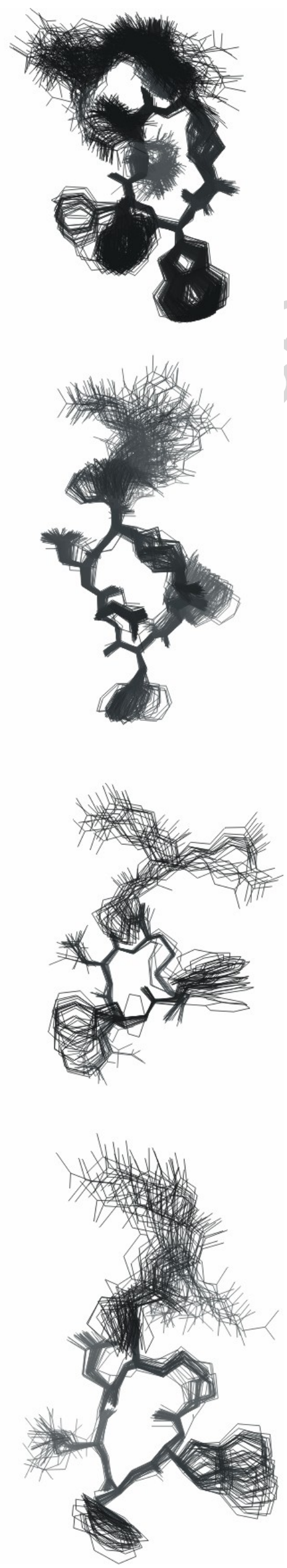
A

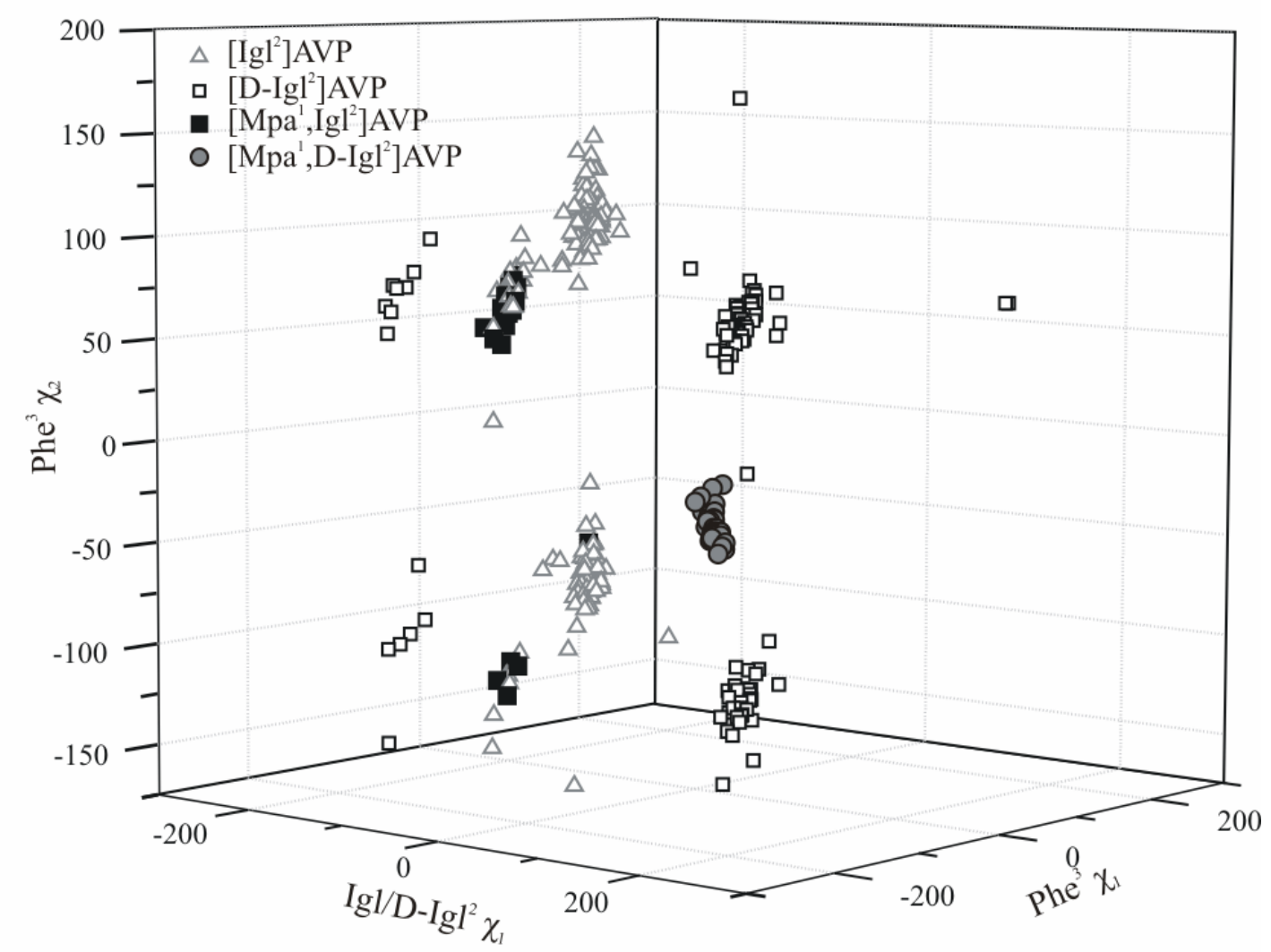

B

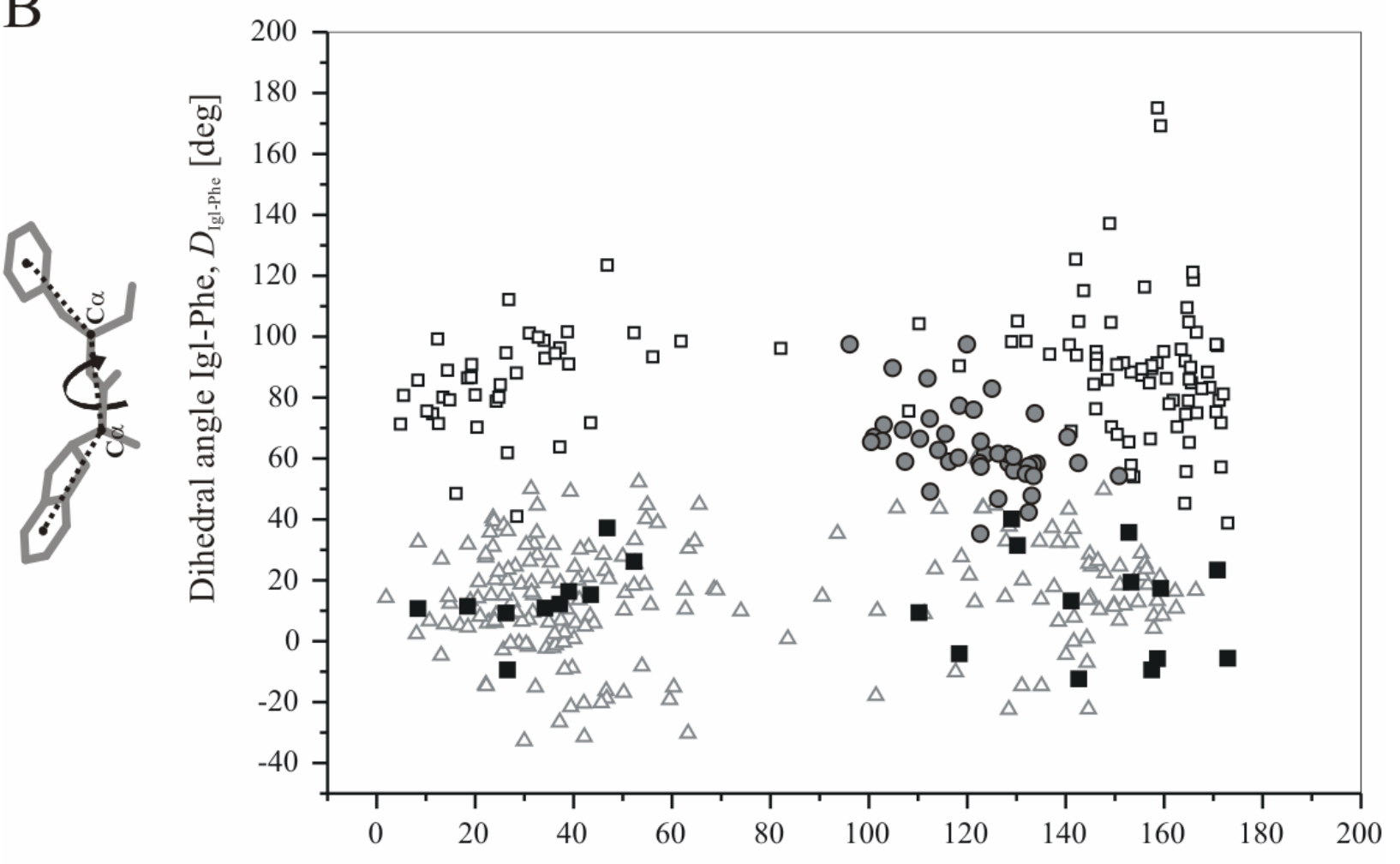

Flat angle Igl-Phe, $F_{\text {Igl-Phe }}$ [deg]

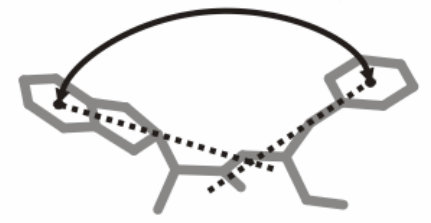


A

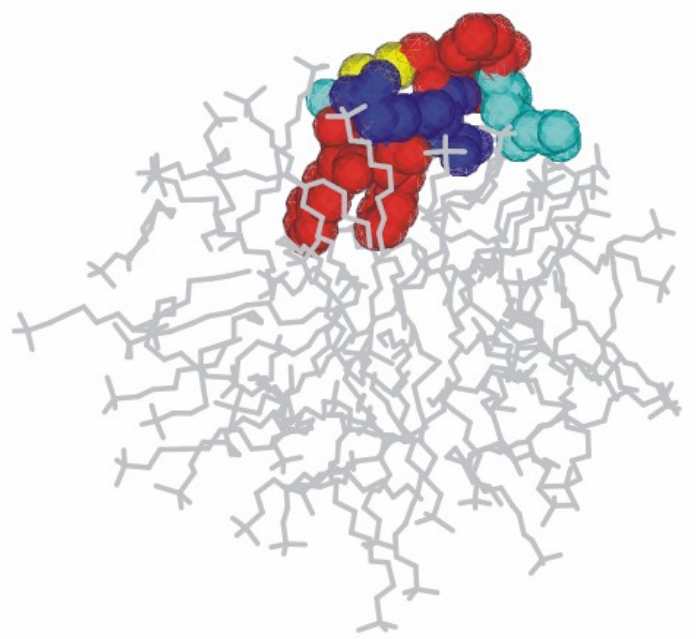

C

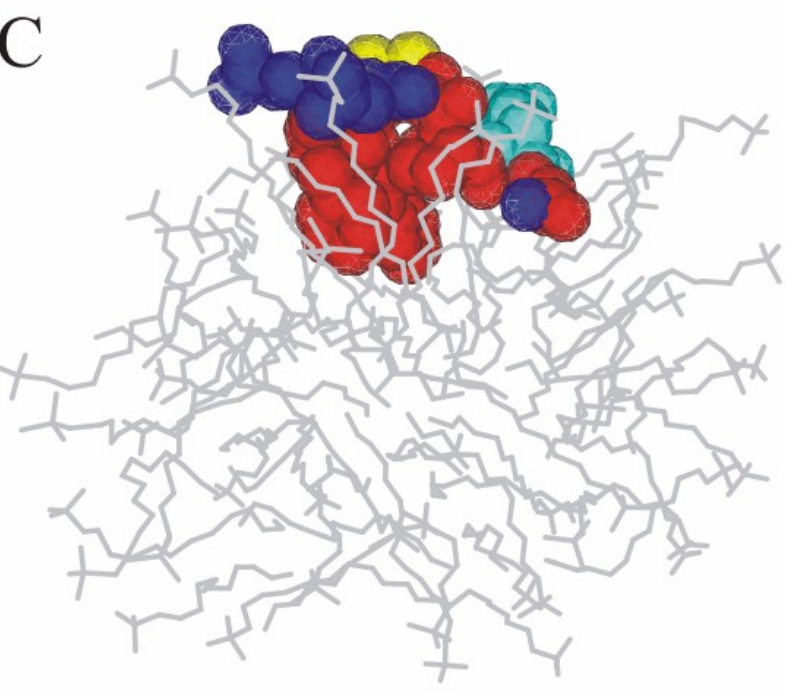

B

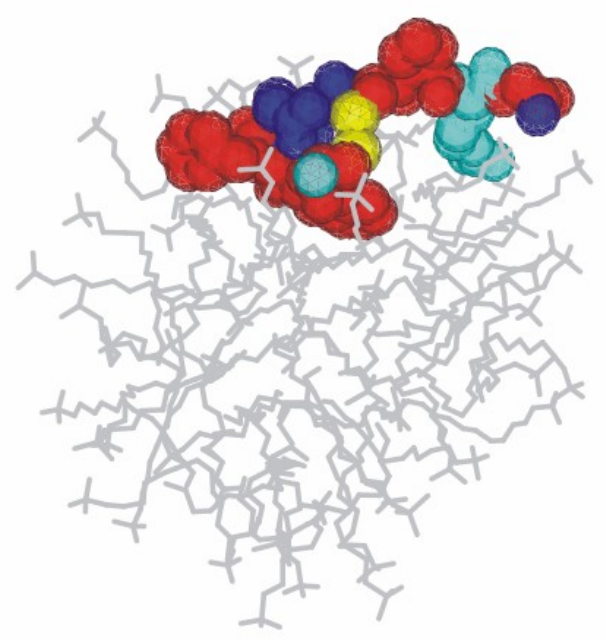

D

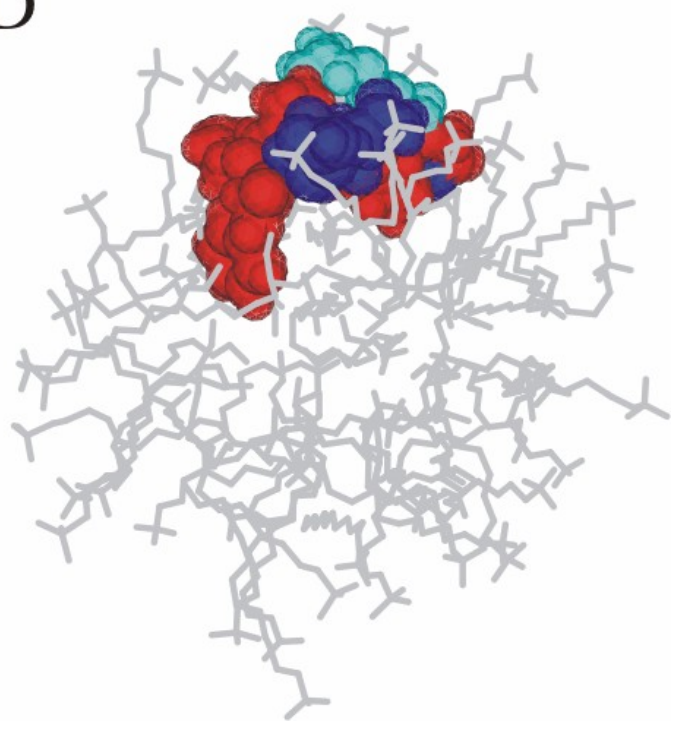



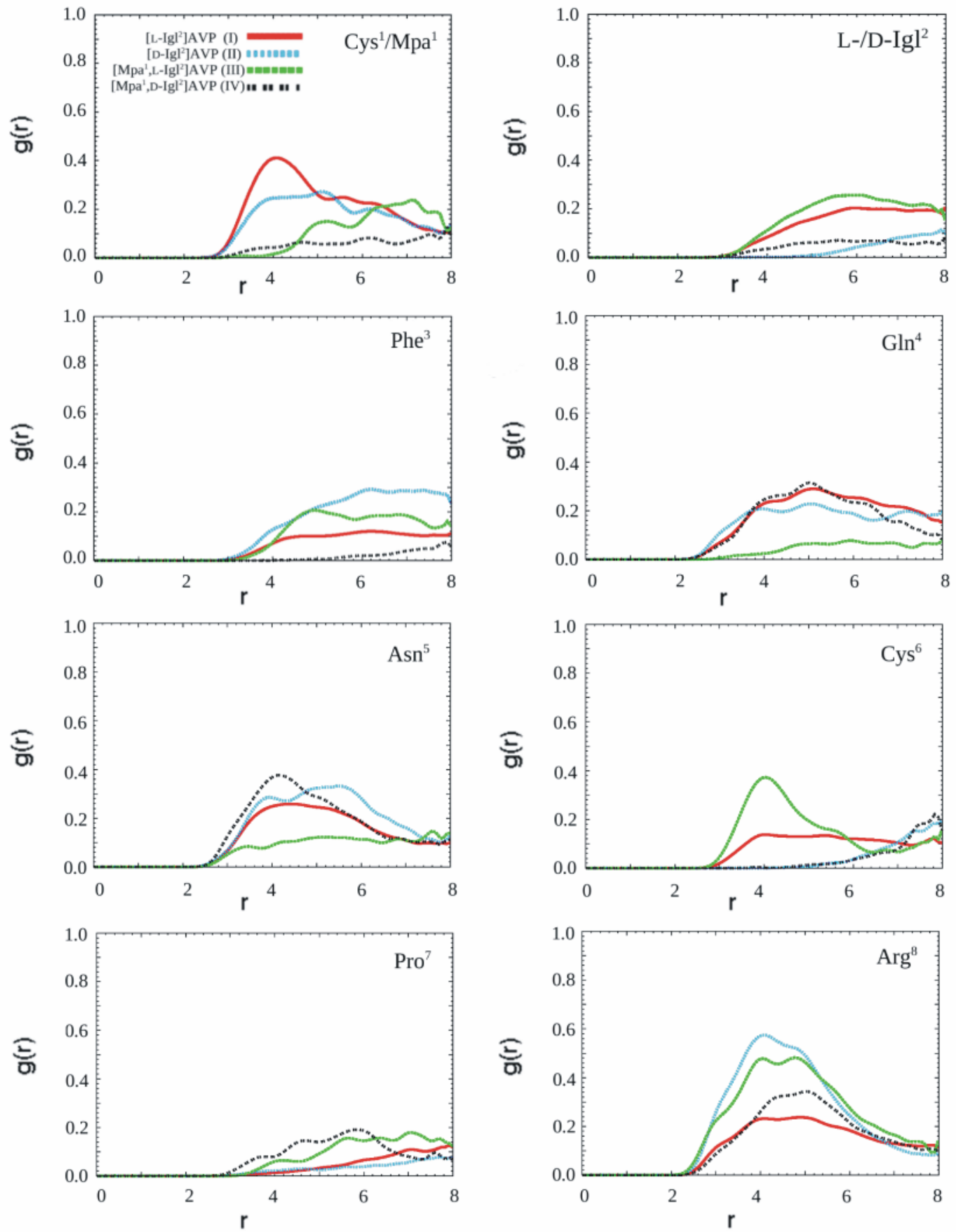

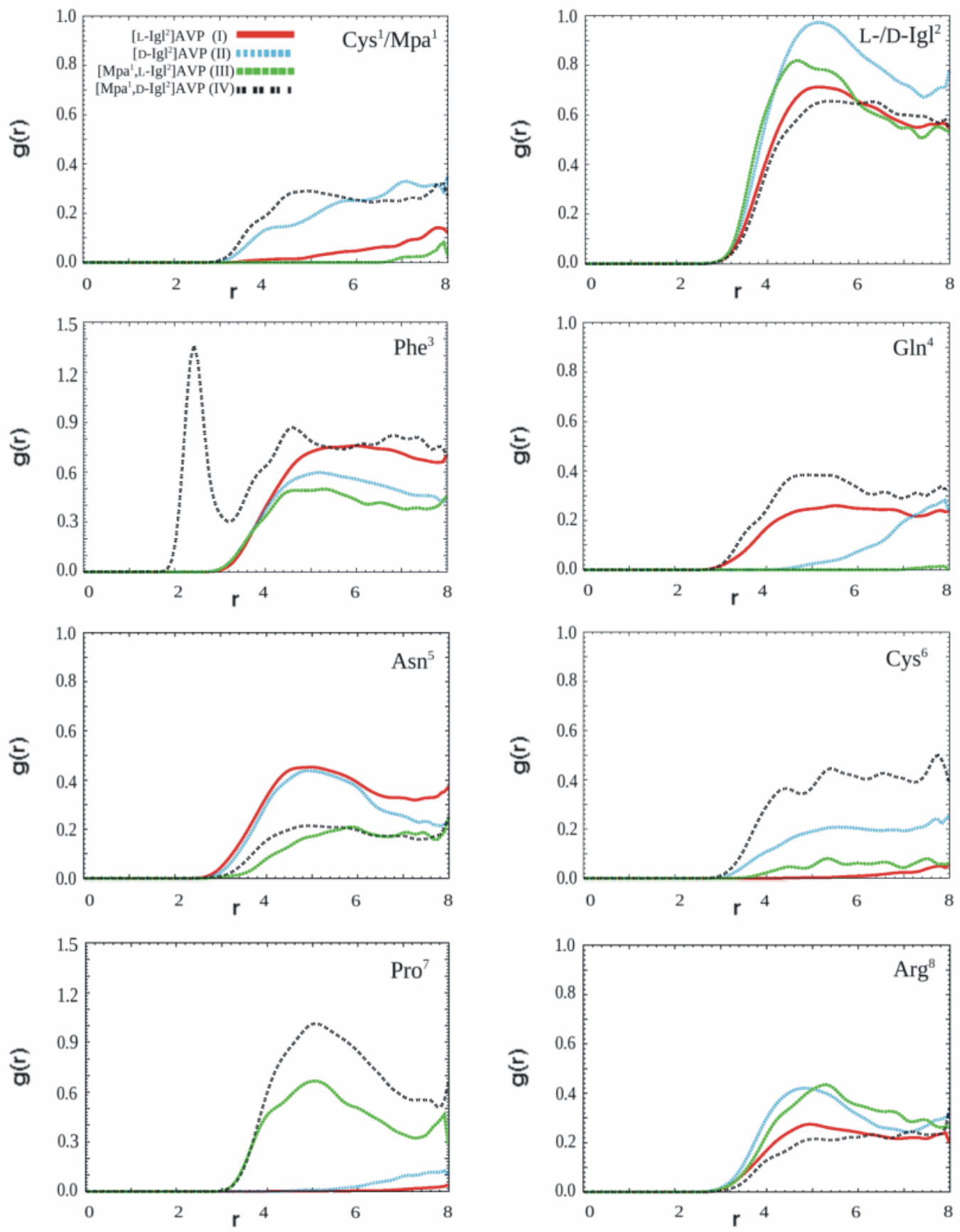
Table 1. Structural statistics for the set of the conformations of $\left[\operatorname{Ig} 1^{2}\right] A V P(I),\left[D-\operatorname{Ig} 1^{2}\right] A V P(I I)$, $\left[\mathrm{Mpa}^{1}, \operatorname{Igl}^{2}\right]$ AVP (III) and $\left[\mathrm{Mpa}^{1}, \mathrm{D}-\operatorname{Igl}^{2}\right]$ AVP (IV) constituting $60 \%$ of the ensemble.

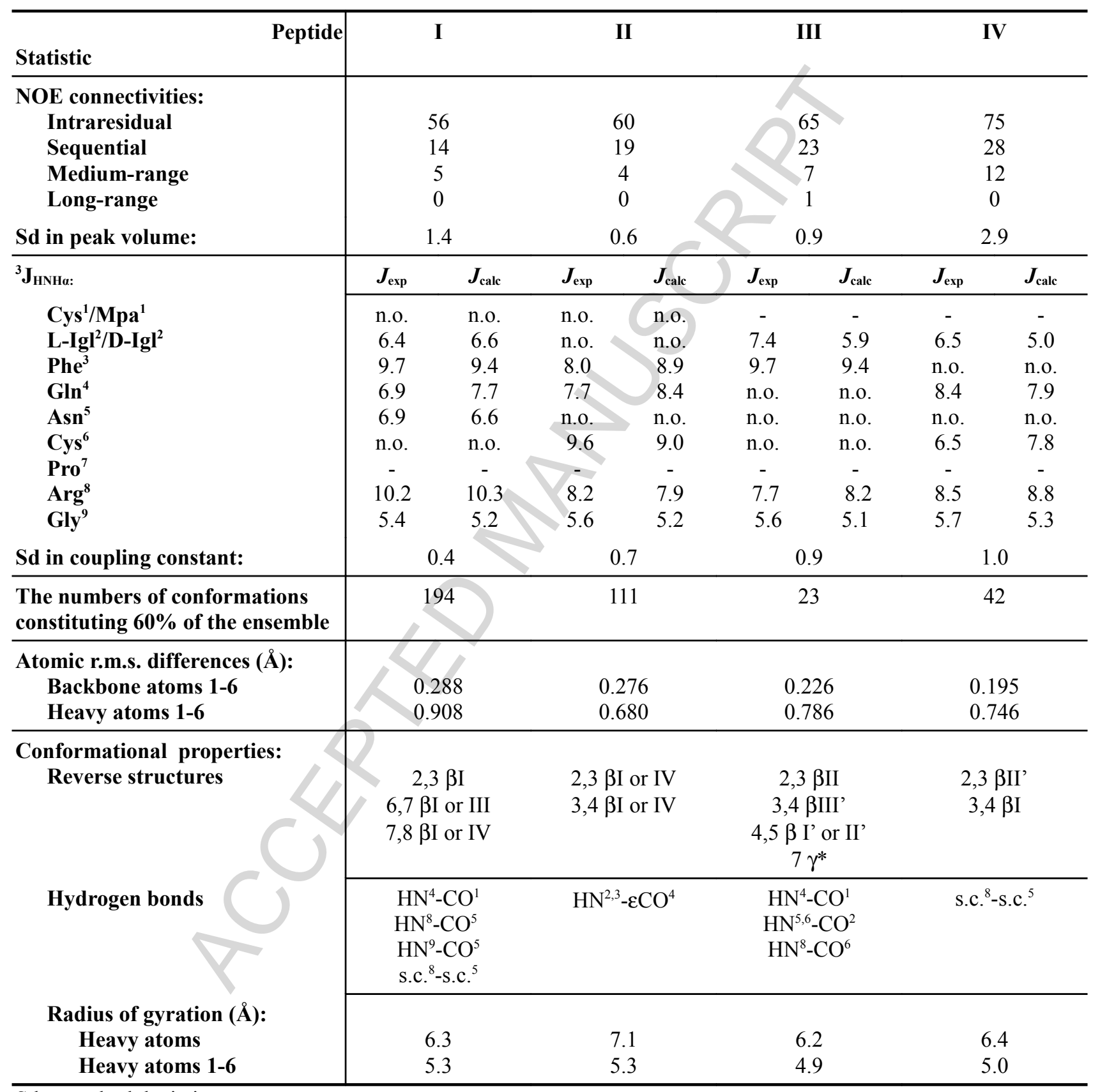

Sd - standard deviation

n.o. - not observed

s.c. - side chain 
Table 2. Hydration numbers for each residue of $\left[\left.\operatorname{Igl}\right|^{2}\right] A V P(I),\left[D-\operatorname{Igl}^{2}\right] A V P(I I),\left[\mathrm{Mpa}^{1}, \operatorname{Igl}^{2}\right]$ AVP (III) and $\left[\mathrm{Mpa}^{1}, \mathrm{D}-\mathrm{Igl}^{2}\right] \mathrm{AVP}$ (IV) in SDS micelle/water system. The hydration numbers were averaged over the conformations with significant weights - comprising $60 \%$ of the ensemble for each analogue.

\begin{tabular}{|c|c|c|c|c|c|c|c|c|}
\hline \multirow{2}{*}{ Residue } & \multicolumn{4}{|c|}{ Carbonyl oxygen } & \multicolumn{4}{|c|}{ Side chains } \\
\hline & I & II & III & IV & I & II & III & IV \\
\hline $\mathrm{Cys}^{1} / \mathbf{M p a}^{1}$ & 0.21 & 0.15 & 0.55 & 0.15 & 0.34 & 0.21 & 0.30 & 0.16 \\
\hline L-Igl ${ }^{2} /$ D-Igl ${ }^{2}$ & 0.09 & 0.00 & 0.02 & 0.40 & 0.05 & 0.01 & 0.01 & 0.05 \\
\hline $\mathbf{P h e}^{3}$ & 0.20 & 0.35 & 0.21 & 0.57 & 0.01 & 0.15 & 0.01 & 0.00 \\
\hline GIn $^{4}$ & 0.36 & 0.19 & 0.56 & 0.64 & 0.27 & 0.25 & 0.48 & 0.17 \\
\hline $\mathbf{A s n}^{5}$ & 0.01 & 0.56 & 0.59 & 0.0 & 0.08 & 0.35 & 0.28 & 0.33 \\
\hline $\mathbf{C y s}^{6}$ & 0.55 & 0.32 & 0.33 & 0.21 & 0.33 & 0.20 & 0.27 & 0.02 \\
\hline Pro $^{7}$ & 0.78 & 0.57 & 0.12 & 0.00 & 0.24 & 0.31 & 0.00 & 0.00 \\
\hline $\operatorname{Arg}^{8}$ & 0.55 & 0.77 & 0.47 & 0.47 & 0.28 & 0.20 & 0.20 & 0.28 \\
\hline Gly $^{9}$ & 0.61 & 0.88 & 0.81 & 0.58 & - & - & - & - \\
\hline
\end{tabular}

